\title{
Screening of Parabens in Natural Water by Salting-out Based Centrifugeless Dispersive Liquid-liquid Microextraction Combined with HPLC-UV
}

\author{
Hadi Farahani* \\ Research Institute of Petroleum Industry (RIPI), P. O. Box 1485733111, Tehran, Iran \\ * Corresponding author: E-mail: farahaniha@ripi.ir \\ Tel.: + 9821 48255261; Fax: + 982144739713
}

Received: 21-01-2018

\begin{abstract}
A simple, efficient and quick salting-out based centrifugeless dispersive liquid-liquid microextraction combined with high-performance liquid chromatography-ultraviolet detection (HPLC-UV) has been successfully developed for the determination of selected parabens in environmental water samples. Herein, following the dispersion of the extracting solvent (1-undecanol) whose melting point is near the room temperature into the sample solution, the cloudy mixture is passed through a test tube filled with sodium chloride, acting as separating agent based on salting-out phenomenon. By immersing the tube inside an ice bath, the fine droplets of the extraction solvent are solidified, easily collected and after returning to the liquid state, injected into HPLC-UV. The values of the detection limit were in the range of 2.5-5.0 $\mu \mathrm{g} \mathrm{L}^{-1}$ while the intra-day $(n=7)$ and inter-day $(n=9$, within three days) precision were below 3.7 and $4.7 \%$, respectively. A satisfactory linearity $\left(0.997 \geq r^{2} \geq 0.996\right)$ and quite a broad linear range $\left(5.0-250 \mu \mathrm{g} \mathrm{L}^{-1}\right)$ were achieved. The relative errors as the accuracy were less than $6.4 \%$ in all experiments. The method was eventually employed for the preconcentration and determination of the analytes in various natural water samples and acceptable results were achieved.
\end{abstract}

Keywords: Centrifugeless dispersive liquid-liquid microextraction, high-performance liquid chromatography-ultra violet detection; natural water; parabens

\section{Introduction}

Parabens (PBs) are well-known synthetic chemicals that are widely applied as antimicrobial preservatives in food, cosmetics, personal care, and pharmaceutical products due to their low cost, water solubility, and high stability. ${ }^{1}$ Despite the low toxicity, they pose a potential health risk to human and wildlife in the long term on account of their estrogenic activities. ${ }^{2}$ The adverse effects comprise disruption to the endocrine system, female breast cancer, irritant contact dermatitis and the development of malignant melanomas. ${ }^{3,4}$ There is a notable concern, although, regarding the ubiquitous use in terms of the possible environmental impacts of PBs. ${ }^{5,6}$ The chemicals may enter the aquatic environment through numerous pathways including discharge of effluents from industries and wastewater treatment plants. ${ }^{7,8}$ Therefore, by raising public attention over the environment, screening of the organic compounds has been considered a substantial issue.

High-performance liquid chromatography (HPLC), ${ }^{9}, 10$ gas chromatography (GC), ${ }^{11,12}$ and capillary electrophore- sis $(\mathrm{CE})^{13,14}$ have been most commonly reported for the determination of PBs in different matrices. Furthermore, the extraction methods which are frequently utilized prior to the instrumental analysis are liquid-liquid extraction $(\mathrm{LLE})^{15}$ and solid phase extraction (SPE) ${ }^{16,17}$. Conversely, the particular methods require either a large amount of sample and organic solvents while they are considered as labor-intensive, time-consuming and costly procedures.

To ameliorate the conventional methodologies, researchers across the world have been aiming towards the development of new approaches which are rapid, inexpensive and environmentally friendly. ${ }^{18}$ The introduction of solid-phase microextraction (SPME) primarily introduced the interest in microextraction methods in the early 1990s. ${ }^{19}$ SPME has obtained expanding popularity in analytical laboratories worldwide attributable to its simplicity, rapidity, sensitivity and high potential for automation. ${ }^{20}$ Simultaneously, attention was given to the application of small volumes of organic solvents for extraction and preconcentration of analytes, named liquid-phase microex- 
traction (LPME). ${ }^{21,22}$ During the last years, LPME as an efficient, simple and quick sample preparation technique combined with widely available instruments, has been extensively applied for preconcentration and determination of interesting analytes. ${ }^{23,24}$

Introduction of dispersive liquid-liquid microextraction (DLLME) in 2006 has considerably contributed towards meeting the mentioned aims of sample pretreatment, owing to its distinctive merits of easy operation, low cost, good enrichment factor, and recovery along with notably short extraction time. ${ }^{25}$ DLLME is based on a ternary component solvent system, in which extraction and disperser solvents are expeditiously injected inside the aqueous sample to make a cloudy solution. After centrifugation, the extraction solvent is sedimented at the bottom of the test tube and removed by a microsyringe for following instrumental analysis. Because of its convenience and quickness, DLLME has been broadly applied for the extraction and preconcentration of numerous types of analytes from various matrices. ${ }^{26,27}$

Recently, Rajabi et al. has published a novel salting-out based centrifugeless DLLME method for the determination of some analytes in several matrices ${ }^{28,29}$ Herein, an organic solvent whose melting point is near the room temperature is dispersed into the sample solution to facilitate the extraction process. Then, by passing the mixture through a test tube filled with a certain amount of sodium chloride, the phase separation is easily achieved. Subsequently and after immersing the tube inside an ice bath, the fine droplets of the extraction solvent are solidified on the top of mixture, collected and after returning to the liquid state, injected into an analytical instrument. This predominant and environmentally friendly method is an efficient and acceptable analytical procedure, for which excellent accuracy and precision are confirmed, being easy and sensitive enough for the enrichment and determination.

The objective of the present study is to assess the salting-out based centrifugeless DLLME technique applicability for the determination of methyl paraben (MP), ethyl paraben (EP), propyl paraben (PP), and butyl paraben (BP) in various natural water samples with quite complex matrices. The factors controlling the microextraction efficiency were investigated in detail and the optimum conditions were properly set. The developed method was in the end validated for the quantitative purposes and employed to real sample analysis in combination with high-performance liquid chromatography-ultraviolet detection (HPLC-UV).

\section{Experimental}

\section{1. Reagents}

Four studied compounds including MP, EP, PP, and BP were purchased in the highest available purities $(\geq$ 99\%) from Alfa Aesar (Lancashire, UK). Analytical re- agent grade methanol, sodium chloride $(\mathrm{NaCl})$, nitric acid $\left(\mathrm{HNO}_{3}\right)$, sodium hydroxide $(\mathrm{NaOH})$, hydrochloric acid $(\mathrm{HCl}, 37 \%)$, acetone, 1-dodecanol, 1 -undecanol and $n$-tetradecane were acquired from Merck Company (Darmstadt, Germany). HPLC grade acetonitrile (Fisher Chemicals, Fair Lawn, NJ, USA) and ultra-pure water (Millipore, Bedford, MA, USA) were used in all experiments. Stock standard solutions of each analyte $\left(100 \mathrm{mg} \mathrm{L}^{-1}\right)$ were prepared in methanol. Working solutions were freshly prepared by diluting the standard solutions with the ultra-pure water to required concentrations. All the solutions were stored at $4{ }^{\circ} \mathrm{C}$ and protected from the light. All glassware and bottles (Schott Duran, Germany) were kept overnight in $20 \%(v / v)$ nitric acid solution and rinsed with the ultra-pure water before use.

\section{2. Apparatus}

A HPLC system (Shimadzu, Kyoto, Japan) including a pump, an automatic injector equipped with $20 \mu \mathrm{L}$ sample loop and a UV detector (set at $254 \mathrm{~nm}$ ) was applied for the analysis of the PBs. The analytical column chosen for the separation was a RP-C18 (LiChrospher, Merck Millipore, Darmstadt, Germany) with $5 \mu \mathrm{m}$ particle size and dimensions of $250 \mathrm{~mm} \times 4.6 \mathrm{~mm}$ i.d., at room temperature of 20 $\pm 0.5^{\circ} \mathrm{C}$. Isocratic elution consisted of acetonitrile and water $(65: 35, v / v)$ at a flow rate of $0.8 \mathrm{~mL} \mathrm{~min}^{-1}$ that was run through the column. The mobile phase was filtered using a $0.2 \mu \mathrm{m}$ membrane filter (Millipore, Bedford, MA, USA) and it was degassed continuously by an online degasser.

\section{3. Real Samples}

The performance of the proposed method was evaluated by analyzing the PBs in four different natural water samples including Caspian Sea (Noushahr Coast, the north part of Iran), Persian Gulf (Bandar Khamir Coast, the south part of Iran), Jajroud River (the east part of Tehran, Iran) and Amir Kabir Dam (the west part of Tehran, Iran). The samples were collected in $1 \mathrm{~L}$ amber glass bottles. The real water samples were filtered before the analysis using a 0.45 $\mu \mathrm{m}$ nylon membrane filter (Whatman, Maid-stone, UK) to eliminate possible solid particles. All the samples were stored in the refrigerator at $4{ }^{\circ} \mathrm{C}$ until their analysis time.

\section{4. The Microextraction Procedure}

The microextraction procedure has been introduced in detail ${ }^{28}$ and presented as a schematic diagram in Fig. 1. To begin with, $10.0 \mathrm{~mL}$ of the sample solution was poured to a $15.0 \mathrm{~mL}$ screw cap glass test tube while $75 \mu \mathrm{L}$ of 1-undecanol was added into the sample solution as the solidifiable extracting solvent. The mixture was quickly sucked into a $10.0 \mathrm{~mL}$ glass syringe and then injected into the tube by a syringe needle for 10 times. Due to the dispersion of fine droplets of the extracting solvent through the aqueous 


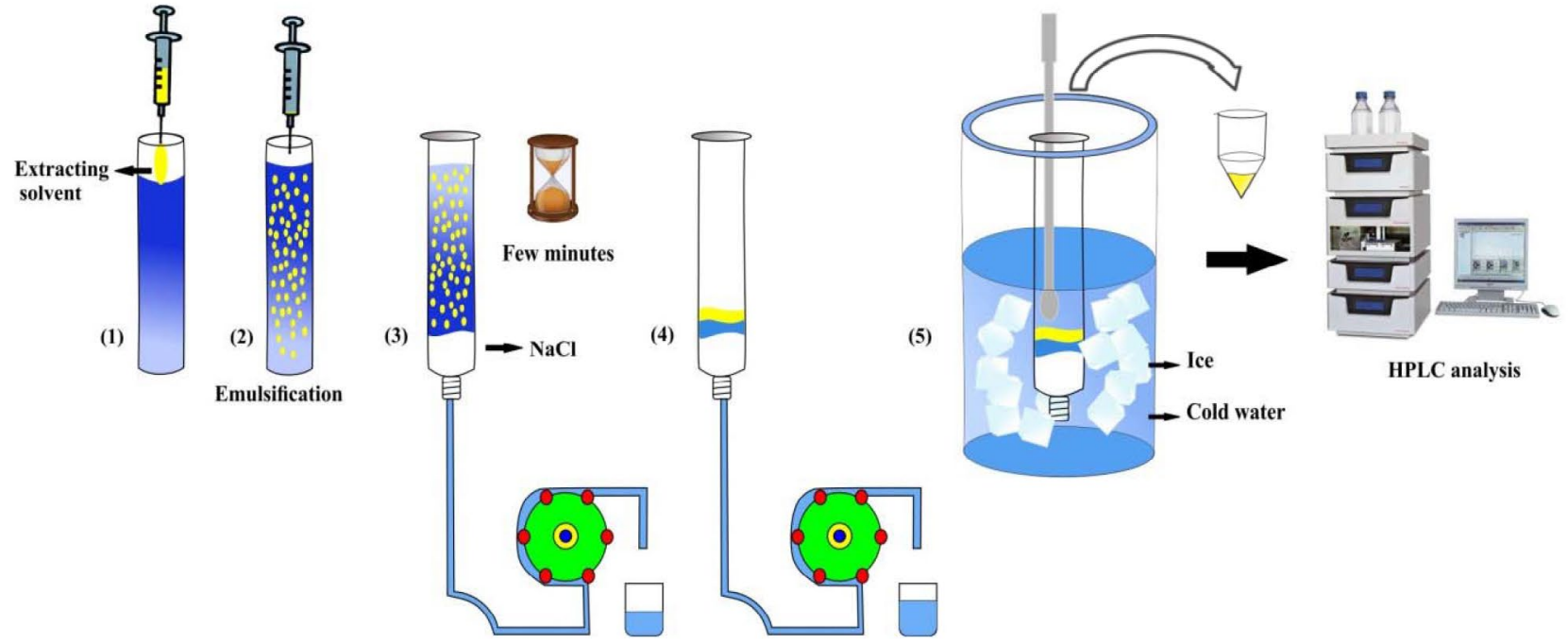

Figure 1. The schematic diagram of the salting-out based centrifugeless DLLME-HPLC.

bulk, the mixture became turbid during every cycle. In the next step, a filter was fixed at the bottom of a cleaned 10.0 $\mathrm{mL}$ glass syringe barrel while $5 \mathrm{~g} \mathrm{NaCl}$ was poured into the barrel and compressed with the syringe plunger. The mixture was then passed through the barrel with a flow rate of $2.0 \mathrm{~mL} \mathrm{~min}{ }^{-1}$. The fine droplets of the extracting solvent rose through the mixture and formed a separate layer on the top of the sample solution which was collected as a result of the salting-out effect. By blocking the bottom of the barrel, the separate layer was immersed in an ice water bath for a few minutes. The extracting solvent was solidified, carefully collected using a spatula and transferred into a small vial, where it melted promptly. In the end, a 20 $\mu \mathrm{L}$ of the extracting phase was injected into the HPLC-UV system for the following analysis.

\section{Results and Discussion}

A one-factor-at-a-time approach was employed to optimize the influencing parameters on the microextraction efficiency. A fixed concentration of the analytes $\left(100.0 \mu \mathrm{g} \mathrm{L}^{-1}\right)$ was used in the optimization process. All the quantifications were performed in the average of three replicate measurements. Blank samples were run to confirm the absence of any interference.

\section{1. The Selection of Extraction Solvent}

Generally, the selection of a proper organic solvent in LPME methods is of great importance for the effective analyte preconcentration. ${ }^{30,31}$ There are some criteria for the solvent selection as follows: it must have a density lower than water and a melting point near or below the room temperature, a low solubility in water, a good chromatographic behavior, high extraction efficiency for the target analytes as well as a good stability. To the best of our knowledge, just a few organic solvents fulfill the mentioned requirements. Among them, 1-dodecanol (density: $0.8309 \mathrm{~g} \mathrm{~mL}^{-1}$; melting point: $22-24{ }^{\circ} \mathrm{C}$ ), 1-undecanol (density: $0.8298 \mathrm{~g} \mathrm{~mL}^{-1}$; melting point: $13-15^{\circ} \mathrm{C}$ ), and $n$-tetradecane (density: 0.756 $\mathrm{g} \mathrm{mL} \mathrm{L}^{-1}$; melting point: $4-6^{\circ} \mathrm{C}$ ) are the most available ones. However, it should be noted that when $n$-tetradecane was used, the phase separation was not well done. Consequently, 1-undecanol and 1-dodecanol were considered as the extraction solvents. As it can be seen in Fig. 2, both solvents offer approximately the same extraction efficiency. From a practical point of view, it is easier to work with 1-undecanol and so, it was selected as the organic extraction solvent.

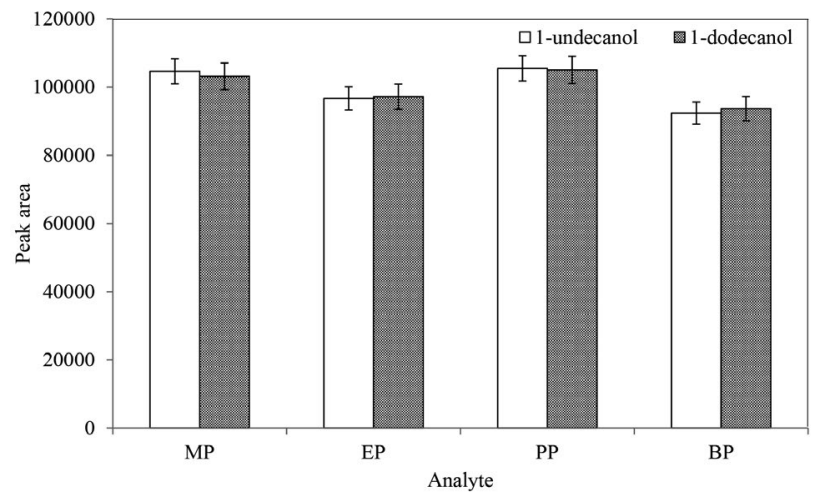

Figure 2. The effect of extraction solvent type on the extraction efficiency. Extraction conditions: sample volume of $10.0 \mathrm{~mL}(100.0 \mu \mathrm{g}$ $\mathrm{L}^{-1}$ of mixed PBs), $\mathrm{pH}$ 13.0; volume of each organic solvent $75 \mu \mathrm{L}$; 10 times of the aspiration-dispersion cycles and the flow rate of the sample solution through $\mathrm{NaCl}$ column of $2.0 \mathrm{~mL} \mathrm{~min}^{-1}$.

\section{2. The $\mathrm{pH}$ of the Sample Solution}

The adjustment of the sample solution $\mathrm{pH}$ is another key parameter to accelerate the extraction process and en- 
hance its efficiency in LPME methods. ${ }^{32,33}$ In this work, as the target compounds are basic $\left(\mathrm{p} K_{\mathrm{a}} \approx 8.5\right)$, the sample solution $\mathrm{pH}$ was adjusted in the proper basic range (preferably 3 units over the $\mathrm{p} K_{\mathrm{a}}$ ), so that the analytes could remain in their undissociated forms and so decrease their solubility in the sample solution. The dependence of the extraction performance on $\mathrm{pH}$ was evaluated in the range of 9-13 with the addition of $\mathrm{NaOH} 4 \mathrm{~mol} \mathrm{~L}^{-1}$ by a micropipette. Based on Fig. 3, the maximum analytical signals were achieved at $\mathrm{pH} 12$ and remained constant thereafter; hence, it was chosen as the optimum value for the subsequent studies.

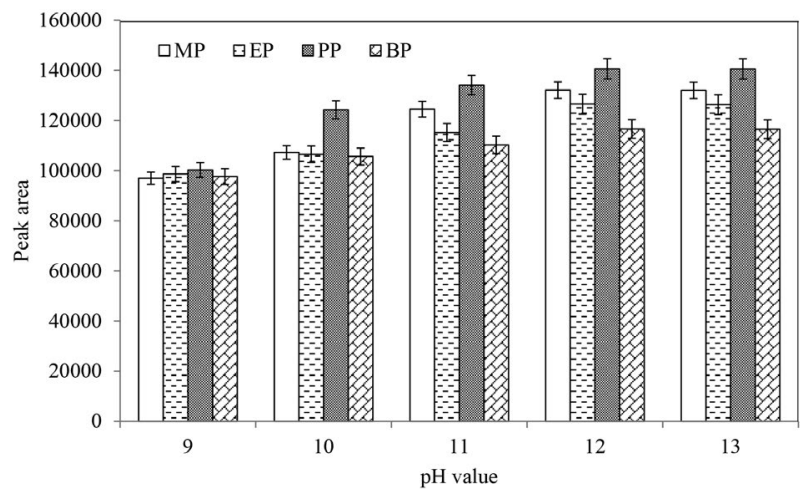

Figure 3. The effect of the sample solution $\mathrm{pH}$ on the extraction efficiency. Extraction conditions: sample volume of $10.0 \mathrm{~mL}(100.0 \mu \mathrm{g}$ $\mathrm{L}^{-1}$ of mixed PBs), 1-undecanol as the extraction solvent; volume of the organic solvent $75 \mu \mathrm{L} ; 10$ times of aspiration-dispersion cycles and the flow rate of the sample solution through $\mathrm{NaCl}$ column of 2.0 $\mathrm{mL} \mathrm{min}^{-1}$.

\section{3. The Volume of the Extraction Solvent}

In LPME techniques, the volume of the extracting solvent is usually chosen as low as possible to reach greater enrichment factors along with having lower toxicity. ${ }^{34}$ In contrast, it should to be satisfactory for the extraction of target analytes and handling the microextraction proce-

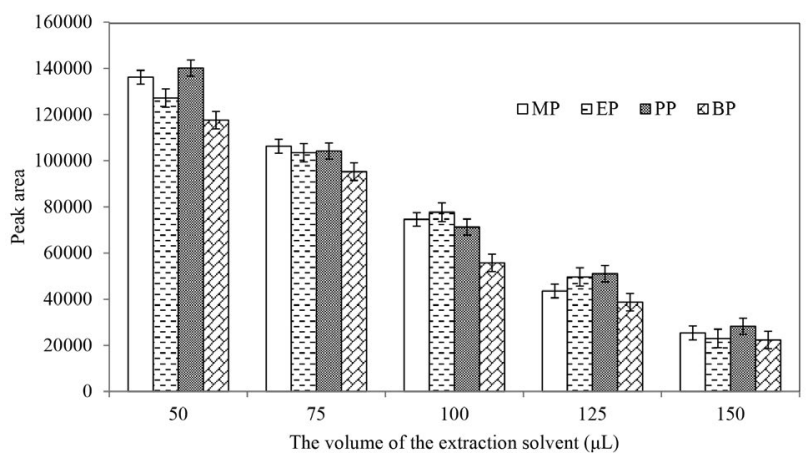

Figure 4. The effect of the volume of the extraction solvent on the method performance. Extraction conditions: sample volume of 10.0 $\mathrm{mL}\left(100.0 \mu \mathrm{g} \mathrm{L} \mathrm{L}^{-1}\right.$ of mixed PBs), 1-undecanol as the extraction solvent; $\mathrm{pH} 12.0 ; 10$ times of aspiration-dispersion cycles and the flow rate of the sample solution through $\mathrm{NaCl}$ column of $2.0 \mathrm{~mL} \mathrm{~min}^{-1}$. dure as well as practically possible for the injection into an analytical instrument. ${ }^{35}$ The effect of the extractant volume on the extraction efficiency was investigated in the range of 50 to $150 \mu \mathrm{L}$. As can be observed in Fig. 4, the peak area drops when the volume rises; it is noticeable that the dilution is the predominant factor for this phenomenon. On the whole and to gain the highest possible sensitivity, $50 \mu \mathrm{L}$ of the extractant solvent was chosen as an optimum value.

\section{4. The Number of Aspiration-Dispersion Cycles}

The number of aspiration-dispersion cycles plays a major role for achieving the highest extraction efficiency along with the least time period. ${ }^{36}$ To obtain the best performance, the parameter was investigated in the range of 4-14 while the other ones were kept constant. It is demonstrated that the analytical signals for all the target analytes were increased with the increase of cycles, up to the 10 and stayed approximately constant afterwards (Fig. 5). Therefore, to obtain satisfactory precision, 12 times of the aspiration-dispersion cycles were selected in the following experiments.

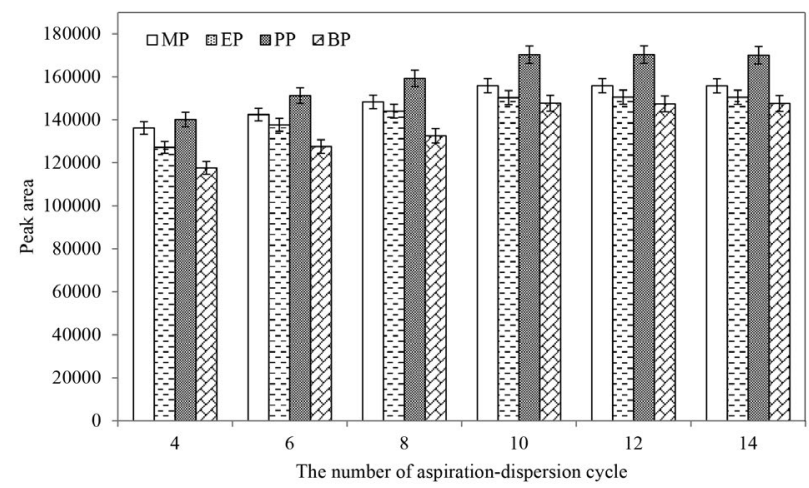

Figure 5. The effect of the number of aspiration-dispersion cycles on the extraction efficiency. Extraction conditions: sample volume of $10.0 \mathrm{~mL}\left(100.0 \mu \mathrm{g} \mathrm{L}^{-1}\right.$ of mixed PBs), 1-undecanol as the extraction solvent and its volume of $50 \mu \mathrm{L} ; \mathrm{pH} 12.0$ and the flow rate of the sample solution through $\mathrm{NaCl}$ column of $2.0 \mathrm{~mL} \mathrm{~min}{ }^{-1}$.

\section{5. The Flow Rate of the Sample Solution Through $\mathrm{NaCl}$ Column}

The flow rate of the sample solution through the barrel filled with $\mathrm{NaCl}$ influences the extraction performance and controls the extraction time. It should be high enough to fairly shorten the extraction time and low enough to amplify the ionic strength and consequently, improves the extraction efficiency owing to the salting-out effect. ${ }^{37}$ This effect has been accounted for decline in the solubility of the target analytes in the aqueous phase and increased partitioning into the organic phase. ${ }^{38}$ The effect of this parameter on the extraction efficiency was examined in the range 
of $1-5 \mathrm{~mL} \mathrm{~min}^{-1}$ by passing a $10.0 \mathrm{~mL}$ of the sample solution through the column applying a peristaltic pump. As shown in Fig. 6, due to the uncomplete salting-out effect at the flow rate above $2.0 \mathrm{~mL} \mathrm{~min}{ }^{-1}$, the extraction efficiency is almost starting to decrease. Therefore, $2.0 \mathrm{~mL} \mathrm{~min}{ }^{-1}$ was chosen as the optimum flow rate value to get the best possible efficiency.

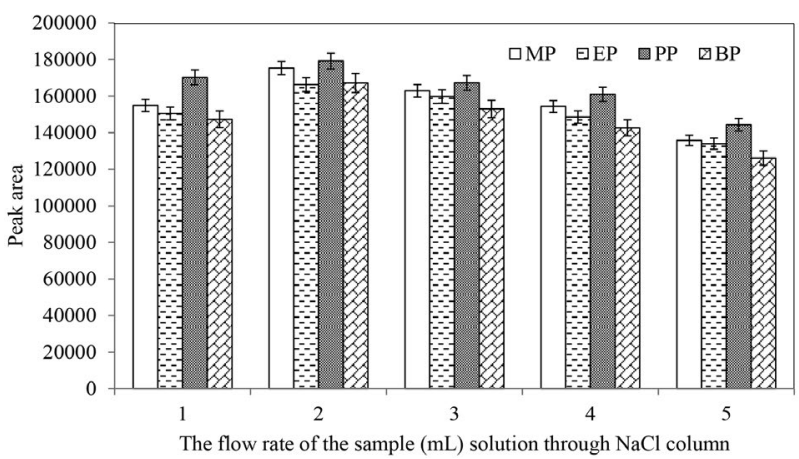

Figure 6. The effect of the flow rate $(\mathrm{mL})$ of the sample solution through $\mathrm{NaCl}$ column on the extraction efficiency. Extraction conditions: sample volume of $10.0 \mathrm{~mL}\left(100.0 \mu \mathrm{g} \mathrm{L} \mathrm{L}^{-1}\right.$ of mixed PBs), 1 -undecanol as the extraction solvent and its volume of $50 \mu \mathrm{L} ; \mathrm{pH}$ 12.0 and 12 times of aspiration-dispersion cycles.

\section{6. The Analytical Figure of Merits}

To assess the applicability of the method, calibration curves were plotted at the optimum conditions using different concentration levels of the analytes. The limit of detection (LOD) based on the signal-to-noise ratio $(\mathrm{S} / \mathrm{N})$ of 3 , the limit of quantitation (LOQ), determination coefficient $\left(r^{2}\right)$ and the linear range (LR) were calculated. As shown in Table 1, LODs and LOQs for the PBs were in the range of 2.5-5.0 $\mu \mathrm{g} \mathrm{L}^{-1}$ and $5.0-10.0 \mu \mathrm{g} \mathrm{L}^{-1}$, respectively, while LRs varied in the range of 5.0-250 $\mu \mathrm{g} \mathrm{L}^{-1}$ with $r^{2}$ of 0.996 to 0.997 .
Table 1. Some quantitative data achieved using salting-out based centrifugeless DLLME and HPLC-UV for the determination of PBs.

\begin{tabular}{lcccc}
\hline Analyte & MP & EP & PP & BP \\
\hline LOD $\left(\mu \mathrm{g} \mathrm{L}^{-1}\right)^{\mathrm{a}}$ & 5.0 & 5.0 & 2.5 & 2.5 \\
$r^{2}$ & 0.996 & 0.997 & 0.996 & 0.997 \\
LOQ $\left(\mu \mathrm{g} \mathrm{L}^{-1}\right)^{\mathrm{b}}$ & 10.0 & 10.0 & 5.0 & 5.0 \\
$\mathrm{LR}\left(\mu \mathrm{g} \mathrm{L}^{-1}\right)^{\mathrm{c}}$ & $10.0-250$ & $10.0-250$ & $5.0-250$ & $5.0-250$ \\
\hline \multicolumn{2}{l}{${ }^{\text {a }}$ Limit of detection for $\mathrm{S} / \mathrm{N}=3}$. & ${ }^{\mathrm{b}}$ Limit of quantitation. & ${ }^{\mathrm{c}}$ Linear \\
$\quad$ range.
\end{tabular}

\section{7. The Precision and Accuracy}

The intra-day and inter-day precision at three concentration levels of each analyte were performed and the results are summarized in Table 2 . As can be seen, intra-assay precision was studied by measuring the samples at 7 runs a day and provided the relative standard deviation (RSD) values within the range of $2.8-3.7 \%$. In addition, the inter-assay precision was determined on the 3-day period at a total run of 9 and RSDs were achieved in the range of $3.8-4.7 \%$. In all experiments, the relative errors as the accuracy of the method were less than $6.4 \%$. The results confirmed that the developed method is quite reliable and repeatable.

\section{8. The Comparisons With Other Methods}

A comparison of the developed method with other formerly reported methods for the determination of PBs in the same media is provided in Table 3. According to the data shown, the present work has reasonable RSDs and adequate LRs compared with the other given methods. The table illustrates that the other methods require special devices or absorbents together with extra sample preparation steps which can be performed by skillful operators. It is important to note that by applying the mass spectrometer,

Table 2. Intra-day and inter-day precision and accuracy for the determination of PBs.

\begin{tabular}{|c|c|c|c|c|c|c|c|}
\hline \multirow[b]{2}{*}{ Compound } & \multirow[b]{2}{*}{$\begin{array}{l}\text { Concentration } \\
\left(\mu \mathrm{g} \mathrm{L}^{-1}\right)\end{array}$} & \multicolumn{2}{|c|}{ Intra-day, $n=7$} & \multirow[b]{2}{*}{$\begin{array}{c}\text { Accuracy } \\
(\%)\end{array}$} & \multicolumn{3}{|c|}{ Inter-day, $n=9$ (three days) } \\
\hline & & $\begin{array}{l}\text { Found value } \\
\qquad\left(\mu g \mathrm{~L}^{-1}\right)^{\mathrm{a}}\end{array}$ & $\begin{array}{c}\text { RSD } \\
(\%)\end{array}$ & & $\begin{array}{l}\text { Found value } \\
\qquad\left(\mu \mathrm{g} \mathrm{L}^{-1}\right)^{\mathrm{a}}\end{array}$ & $\begin{array}{c}\text { RSD } \\
(\%)\end{array}$ & $\begin{array}{c}\text { Accuracy } \\
(\%)\end{array}$ \\
\hline \multirow[t]{3}{*}{ MP } & 10 & 10.3 & 3.7 & 103 & 10.4 & 4.7 & 104 \\
\hline & 100 & 94.1 & 3.5 & 94 & 103.3 & 4.3 & 103 \\
\hline & 200 & 211.6 & 3.1 & 106 & 210.7 & 4.0 & 105 \\
\hline \multirow[t]{3}{*}{ EP } & 10 & 10.5 & 3.6 & 105 & 10.6 & 4.5 & 106 \\
\hline & 100 & 104.2 & 3.2 & 104 & 95.5 & 4.1 & 96 \\
\hline & 200 & 191.2 & 2.8 & 104 & 207.7 & 3.9 & 104 \\
\hline \multirow[t]{3}{*}{$\mathrm{PP}$} & 10 & 9.6 & 3.4 & 96 & 10.6 & 3.8 & 106 \\
\hline & 100 & 105.6 & 3.3 & 106 & 96.3 & 4.6 & 96 \\
\hline & 200 & 193.4 & 2.9 & 97 & 189.7 & 4.2 & 95 \\
\hline \multirow[t]{3}{*}{ BP } & 10 & 9.4 & 3.7 & 94 & 10.5 & 4.6 & 105 \\
\hline & 100 & 105.7 & 3.4 & 106 & 106.4 & 4.5 & 106 \\
\hline & 200 & 209.3 & 3.0 & 105 & 192.8 & 4.0 & 96 \\
\hline
\end{tabular}

\footnotetext{
${ }^{\text {a }}$ The average of three independent measurements.
} 
Table 3. The comparison of the current method with the other methods for the determination of PBs.

\begin{tabular}{|c|c|c|c|c|c|c|}
\hline Method & $\begin{array}{l}\text { Sample } \\
\text { matrix }\end{array}$ & $\operatorname{LOD}\left(\mu \mathrm{g} \mathrm{L}^{-1}\right)$ & $\mathrm{LR}\left(\mu \mathrm{g} \mathrm{L}^{-1}\right)$ & RSD\% & $\begin{array}{l}\text { Extraction time } \\
\text { (minute) }\end{array}$ & Reference \\
\hline SA-D- $\mu$-SPE-GC-PID ${ }^{(a)}$ & Water & $0.05-0.3$ & $0.2-50$ & $6.0-8.0$ & 20 & 39 \\
\hline AME-HPLC-DAD ${ }^{(b)}$ & Water & $1.0-6.5$ & $3.2-500$ & $3.0-22$ & 90 & 40 \\
\hline VA-D- $\mu$-SPE-HPLC-DAD ${ }^{(c)}$ & Water & $0.1-0.6$ & $1.0-147$ & $1.7-16$ & 20 & 41 \\
\hline RDSE-GC-MS/MS ${ }^{(\mathrm{d})}$ & Water & $0.02-0.05$ & $0.06-250$ & $2.0-9.0$ & 85 & 42 \\
\hline $\begin{array}{l}\text { Salting-out based centrifugeless- } \\
\text { DLLME-HLPC-UV }{ }^{(\mathrm{e})}\end{array}$ & Water & $2.5-5.0$ & $5.0-250$ & $2.8-4.7$ & 7.5 & $\begin{array}{c}\text { Presented } \\
\text { method }\end{array}$ \\
\hline
\end{tabular}

(a) Solvent-assisted dispersive micro solid phase extraction and gas chromatography-photoionization detector (b) Adsorptive microextraction and high performance liquid chromatography-diode array detection ${ }^{(c)}$ Vortex-assisted dispersive micro solid-phase extraction and high performance liquid chromatography-diode array detection ${ }^{(\mathrm{d})}$ Rotating disk sorptive extraction and gas chromatography-tandem mass spectrometry (e) Dispersive liquid-liquid microextraction and high performance liquid chromatography-ultraviolet detection

the LODs would significantly decrease whereas the analysis cost remarkably increase. The most obvious point is that when it comes to the comparison of the extraction time, the presented method stands in the first order.

\subsection{Analysis of the Environmental Water Samples}

Set at the optimum conditions, the method performance was tested by analyzing the PBs in the four different environmental water samples. The results are presented in Table 4 and showed that they were free of PBs contamination. It is worth noting that the method is a non-exhaustive extraction procedure and therefore the relative recovery (determined as the ratio of the concentrations found in the real sample and the pure water sample, spiked with a same quantity of the analytes), rather than the absolute recovery (applied in exhaustive extraction methods), was employed. Therefore, as to evaluate the matrix effects all the real samples were spiked with PBs standards at different concentration levels and the relative recovery experiments of the analytes are calculated (Table 4). The obtained recoveries were between $93-106 \%$, indicating that the method is not influenced by the matrix in actual applications, while the RSD values were below than $3.9 \%(n=7)$. An overlay of two chromatograms obtained by applying the method for the Persian Gulf (Bandar Khamir Coast, Iran) sample before and after PBs spiking are shown in Fig. 7 and demonstrated no significant interference through the analytical procedure.

Table 4. The results obtained from the analysis of the natural water samples.

\begin{tabular}{|c|c|c|c|c|}
\hline Sample & MP & EP & $\mathbf{P P}$ & BP \\
\hline \multicolumn{5}{|c|}{ Caspian Sea (Noushahr Coast, Iran), (10.0 $\mu \mathrm{g} \mathrm{L} \mathrm{L}^{-1}$ added $)$} \\
\hline PBs concentration $\left(\mu \mathrm{g} \mathrm{L}^{-1}\right)$ & $\mathrm{ND}^{\mathrm{a}}$ & ND & ND & ND \\
\hline Found after spike $\left(\mu \mathrm{g} \mathrm{L}^{-1}\right)$ & 10.4 & 9.5 & 9.3 & 9.7 \\
\hline Relative recovery\% & 104 & 95 & 93 & 97 \\
\hline $\mathrm{RSD} \%(n=7)$ & 3.1 & 3.6 & 3.0 & 3.9 \\
\hline \multicolumn{5}{|c|}{ Persian Gulf (Bandar Khamir Coast, Iran), $(25.0 \mu \mathrm{g} \mathrm{L}-1$ added $)$} \\
\hline PBs concentration $\left(\mu \mathrm{g} \mathrm{L}^{-1}\right)$ & ND & ND & ND & ND \\
\hline Found after spike $\left(\mu \mathrm{g} \mathrm{L}^{-1}\right)$ & 26.2 & 24.1 & 23.7 & 26.5 \\
\hline Relative recovery\% & 105 & 96 & 95 & 106 \\
\hline $\mathrm{RSD} \%(n=7)$ & 3.8 & 3.3 & 3.6 & 3.4 \\
\hline \multicolumn{5}{|c|}{ Jajroud River (Tehran, Iran), (50.0 $\mu \mathrm{g} \mathrm{L} \mathrm{L}^{-1}$ added) } \\
\hline PBs concentration $\left(\mu \mathrm{g} \mathrm{L}^{-1}\right)$ & ND & ND & ND & ND \\
\hline Found after spike $\left(\mu \mathrm{g} \mathrm{L}^{-1}\right) 51.7$ & 52.1 & 48.3 & 50.9 & \\
\hline Relative recovery\% & 103 & 104 & 97 & 102 \\
\hline $\operatorname{RSD} \%(n=7)$ & 3.4 & 3.5 & 3.9 & 3.7 \\
\hline \multicolumn{5}{|c|}{ Amir Kabir Dam (Tehran, Iran), (100.0 $\mu \mathrm{g} \mathrm{L}^{-1}$ added) } \\
\hline PBs concentration $\left(\mu \mathrm{g} \mathrm{L}^{-1}\right)$ & ND & ND & ND & ND \\
\hline Found after spike $\left(\mu \mathrm{g} \mathrm{L}^{-1}\right) 104.1$ & 94.9 & 97.2 & 96.4 & \\
\hline Relative recovery $\%$ & 104 & 95 & 97 & 96 \\
\hline $\mathrm{RSD} \%(n=7)$ & 3.7 & 3.1 & 3.6 & 3.2 \\
\hline
\end{tabular}

${ }^{\mathrm{a}}$ Not detected. 


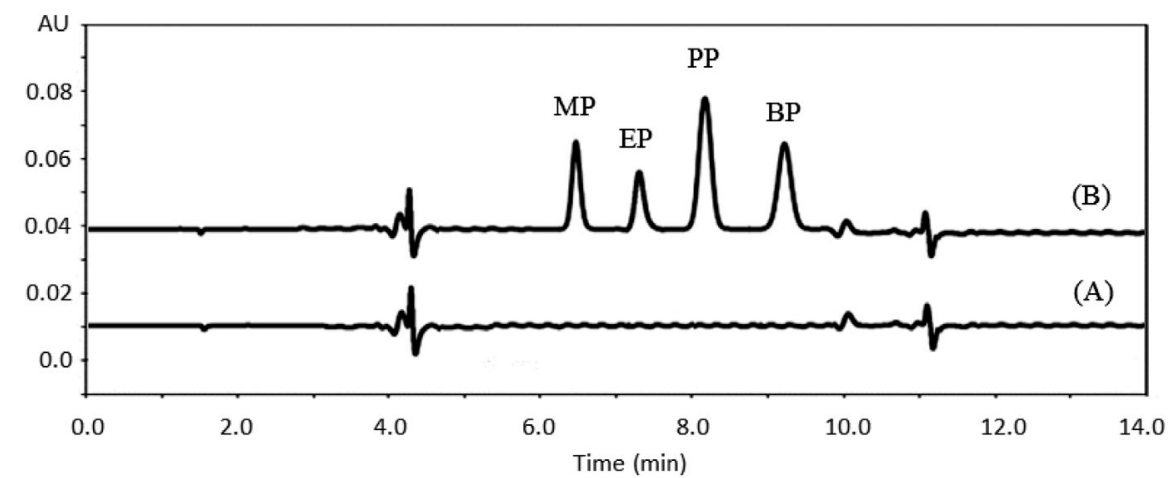

Figure 7. An overlay of two HPLC chromatograms obtained by performing salting-out based centrifugeless DLLME and HPLC-UV for the Persian Gulf water sample (Bandar Khamir Coast, Iran), before (A) and after PBs spiking (B).

\section{Conclusions}

The aim of the present study was to develop and validate a rapid, robust and reliable method combined with HPLC-UV for the determination of the PBs in environmental water samples. The satisfactory extraction efficiency, sufficient sensitivity, and repeatability along with significant accuracy and linearity were achieved, almost independent of the complex matrix in the real sample analysis. Moreover, it needs just a little volume of organic extractants, being consequently an environmentally friendly approach of the sample preparation. The entire analytical procedure presents a cost-effective and quick way for screening purposes. Therefore, putting all the advantages together, the developed method possesses a great potential to be applied in the other applications.

\section{Disclosure statement}

The authors declare no conflicts of interest.

\section{References}

1. D. Błędzka, J. Gromadzińska, W. Wąsowicz, Environ. Int., 2014, 67, 27-42. DOI:10.1016/j.envint.2014.02.007

2. E. P. Hines, P. Mendola, O. S. von Ehrenstein, X. Ye, A. M. Calafat, S. E. Fenton, Reprod. Toxicol., 2015, 54, 120-128. DOI:10.1016/j.reprotox.2014.11.006

3. S. Pan, C. Yuan, A. Tagmount, R. A. Rudel, J. M. Ackerman, P. Yaswen, C. D. Vulpe, D. C. Leitman, Environ. Health Perspect., 2015, 124, 563-569. DOI:10.1289/ehp.1409200

4. F. Artacho-Cordón, M. F. Fernández, H. Frederiksen, L. M. Iribarne-Durán, I. Jiménez-Díaz, F. Vela-Soria, A. M. Andersson, P. Martin-Olmedo, F. M. Peinado, N. Olea, J. P. Arrebola, Environ. Int., 2018, 119, 203-211.

DOI:10.1016/j.envint.2018.05.052

5. L. Quirós-Alcalá, J. P. Buckley, M. Boyle, Int. J. Hyg. Environ. Health, 2018, 221, 652-660. DOI:10.1016/j.ijheh.2018.03.006

6. L. Kolatorova, J. Vitku, R. Hampl, K. Adamcova, T. Skodova,
M. Simkova, A. Parizek, L. Starka, M. Duskova, Environ. Res., 2018, 163, 115-122. DOI:10.1016/j.envres.2018.01.031

7. C. Haman, X. Dauchy, C. Rosin, J. F. Munoz, Water Res., 2015, 68, 1-11. DOI:10.1016/j.watres.2014.09.030

8. R. Karthikraj, A. K. Vasu, K. Balakrishna, R. K. Sinha, K. Kannan, Sci. Total Environ., 2017, 593, 592-598.

DOI:10.1016/j.scitotenv.2017.03.173

9. X. Ye, L. J. Tao, L. L. Needham, A. M. Calafat, Talanta, 2008, 76, 865-871. DOI:10.1016/j.talanta.2008.04.034

10. X. Ye, A. M. Bishop, L. L. Needham, A. M. Calafat, Anal. Chim. Acta , 2008, 622, 150-156. DOI:10.1016/j.aca.2008.05.068

11. G. Shanmugam, B. R. Ramaswamy, V. Radhakrishnan, H. Tao, Microchem. J., 2010, 96, 391-396.

DOI:10.1016/j.microc.2010.07.005

12. B. R. Ramaswamy, G. Shanmugam, G. Velu, B. Rengarajan, D. J. Larsson, J. Hazard. Mater., 2011, 186, 1586-1593. DOI:10.1016/j.jhazmat.2010.12.037

13. L. Labat, E. Kummer, P. Dallet, J. P. Dubost, J. Pharm. Biomed. Anal., 2000, 23, 763-769.

DOI:10.1016/S0731-7085(00)00358-7

14. U. D. Uysal, T. Güray, J. Anal. Chem., 2008, 63, 982-986. DOI:10.1134/S1061934808100109

15. N. Cabaleiro, I. De La Calle, C. Bendicho, I. Lavilla, Anal. Methods, 2013, 5, 323-340. DOI:10.1039/C2AY25830G

16. X. Ye, Z. Kuklenyik, A. M. Bishop, L. L. Needham, A. M. Calafat, J. Chromatogr. B, 2006, 844, 53-59.

DOI:10.1016/j.jchromb.2006.06.037

17. I. Márquez-Sillero, E. Aguilera-Herrador, S. Cárdenas, M. Valcárcel, J. Chromatogr. A, 2010, 1217, 1-6.

DOI:10.1016/j.chroma.2009.11.005

18. S. Mitra (Ed.): Sample Preparation Techniques in Analytical Chemistry, John Wiley \& Sons, 2003. ISBN: 978-0-47132845-2

19. C. L. Arthur, J. Pawliszyn, Anal. Chem., 1990, 62, 2145-2148. DOI:10.1021/ac00218a019

20. H. Piri-Moghadam, F. Ahmadi, J. Pawliszyn, TrAC, Trends Anal. Chem., 2016, 85, 133-143.

DOI:10.1016/j.trac.2016.05.029

21. Y. Yan, X. Chen, S. Hu, X. Bai, J. Chromatogr. A, 2014, 1368, 1-17. DOI:10.1016/j.chroma.2014.09.068 
22. A. Spietelun, Ł. Marcinkowski, M. de la Guardia, J. Namieśnik, Talanta, 2014, 119, 34-45.

DOI:10.1016/j.talanta.2013.10.050

23. S. Kapitány, E. Sóki, J. Posta, Á. Béni, Acta Chim. Slov., 2017, 64, 248-255. DOI:10.17344/acsi.2017.3137

24. J. Vichapong, Y. Santaladchaiyakit, R. Burakham, S. Srijaranai, S., Acta Chim. Slov., 2017, 64, 590-597.

DOI:10.17344/acsi.2017.3336

25. M. Rezaee, Y. Assadi, M. R. M. Hosseini, E. Aghaee, S. Berijani, J. Chromatogr. A, 2006, 1116, 1-9.

DOI:10.1016/j.chroma.2006.03.007

26 E. L. Ç. İ. Latif, A. Hol, A. A. Kartal, A. Akdogan, E. L. Ç. İ. Aydan, T. Arslan, Acta Chim. Slov., 2014, 62, 196-203.

DOI:10.17344/acsi.2014.897

27. E Kupcová, K. Reiffová, J. Sep. Sci., 2017, 40, 2620-2628. DOI:10.1002/jssc.201700123

28. E. Mirparizi, M. Rajabi, M. Bazregar, A. Asghari, Anal. Bioanal. Chem., 2017, 409, 3007-3016.

DOI:10.1007/s00216-017-0246-5

29. M. Bazregar, M. Rajabi, Y. Yamini, S. Arghavani-Beydokhti, A. Asghari, Food Chem., 2018, 244, 1-6.

DOI:10.1016/j.foodchem.2017.10.006

30. A. Sarafraz-Yazdi, A. Amiri, TrAC, Trends Anal. Chem., 2010, 29, 1-14. DOI:10.1016/j.trac.2009.10.003

31. E. Psillakis, N. Kalogerakis, TrAC, Trends Anal. Chem., 2003, 22, 565-574. DOI:10.1016/S0165-9936(03)01007-0

32. S. Dadfarnia, A. M. H. Shabani, Anal. Chim. Acta, 2010, 658, 107-119. DOI:10.1016/j.aca.2009.11.022
33. S. Pedersen-Bjergaard, K. E. Rasmussen, J. Chromatogr. B, 2005, 817, 3-12. DOI:10.1016/j.jchromb.2004.08.034

34. F. Pena-Pereira, I. Lavilla, C. Bendicho, TrAC, Trends Anal. Chem., 2010, 29, 617-628.

DOI:10.1016/j.trac.2010.02.016

35. E. Stanisz, J. Werner, A. Zgoła-Grześkowiak, TrAC, Trends Anal. Chem., 2014, 61, 54-66.

DOI:10.1016/j.trac.2014.06.008

36. S. Arghavani-Beydokhti, M. Rajabi, M. Bazregar, A. Asghari, Anal. Methods, 2017, 9, 1732-1740. DOI:10.1039/C6AY03477B

37. J. Liu, M. Jiang, G. Li, L. Xu, M. Xie, Anal. Chim. Acta, 2010, 679, 74-80. DOI:10.1016/j.aca.2010.09.013

38. G. G. Noche, M. E. F. Laespada, J. L. P. Pavón, B.M. Cordero, S. M. Lorenzo, J. Chromatogr. A, 2011, 1218, 6240-6247. DOI:10.1016/j.chroma.2011.06.112

39. M. Abbasghorbani, A. Attaran, M. Payehghadr, J. Sep. Sci., 2013, 36, 311-319. DOI:10.1002/jssc.201200556

40. A. Neves Dias, A. Cristine da Silva, V. Simão, J. Merib, E. Carasek, Anal. Chim. Acta, 2015, 888, 59-66.

DOI:10.1016/j.aca.2015.07.011

41. P. Rocío-Bautista, C. Martínez-Benito, V. Pino, J. Pasán, J. H. Ayala, C. Ruiz-Pérez, A. M. Afonso, Talanta, 2015, 139, 13-20. DOI:10.1016/j.talanta.2015.02.032

42. M. Becerra-Herrera, V. Miranda, D. Arismendi, P. Richter, Talanta, 2018, 176, 551-557.

DOI:10.1016/j.talanta.2017.08.071

\section{Povzetek}

Uspešno smo razvili preprosto, učinkovito in hitro disperzivno mikroekstrakcijo s topili brez centrifugiranja, osnovano na izsoljevanju, ki smo jo skupaj z visokoločljivostno tekočinsko kromatografijo z UV detekcijo (HPLC-UV) uporabili za določanje izbranih parabenov v okoljskih vodnih vzorcih. Po disperziji ekstrakcijskega topila (1-undekanol) s tališčem blizu sobne temperature v vzorec se motno zmes spusti skozi epruveto, napolnjeno s trdnim natrijevim kloridom. Slednji deluje kot separacijsko sredstvo na osnovi izsoljevanja. Potem se epruveto potopi v ledeno kopel, pri čemer se drobne kapljice ekstrakcijskega topila strdijo in se jih da zlahka pobrati in po ponovnem utekočinjenju injicirati v HPLC-UV. Meje zaznave so bile v območju 2,5-5,0 $\mu \mathrm{g} \mathrm{L}^{-1}$, medtem ko je bila ponovljivost znotraj dneva $(n=7)$ pod $3,7 \%$ in med dnevi $\left(n=9\right.$, trije dnevi) pod 4,7\%. Metoda je imela zadovoljivo linearnost $\left(0,997 \geq r^{2} \geq 0,996\right)$ in dokaj široko linearno območje (5,0-250 $\left.\mathrm{g} \mathrm{L} \mathrm{L}^{-1}\right)$. Relativna napaka pri točnosti je bila pod 6,4\% v vseh poskusih. Metodo smo na koncu uporabili za predkoncentracijo in določitev analitov v različnih vzorcih naravnih vod ter dobili sprejemljive rezultate.

Except when otherwise noted, articles in this journal are published under the terms and conditions of the Creative Commons Attribution 4.0 International License 